\title{
When narratology does not travel well: introduction
}

\section{Guoqiang Qiao'}

Published online: 11 September 2018

C Akadémiai Kiadó, Budapest, Hungary 2018

Narratology, as a discipline, has been traveling nearly for 50 years since Tzvetan Todorov invented the term "narratology" in 1969. Throughout its travels, it has been enriched by taking in so many beautiful landscapes, vivid stories, and valuable treasures. Meanwhile, it transgresses or bypasses so many not-taken roads that are filled with distracting scenes and stories. So far, narratology has developed so many challenging concepts that are either central to narratology or (a bit) far away from it, splitting the mono-centrism into multi-centrism. Narratology that is heavily reliant on structuralism is no longer regarded as a master theory, even though it has sorted out most of the basic elements and models and schemas of narrative, uncovered the laws and rules and proposed most of the preliminary issues and thus can be applied to all kind of narrative analysis. It is now expected to meet different requirements of culture, literature, politics, ethics, ethnics, gender, genre, and so on to make it as an efficient tool for analyzing varieties of narrative complexities.

In the West, narratology witnesses a period of steady and ineluctable decline and eventually gives way to the so-called new narratologies or postclassical narratology. Its polysemic and multi-purposed characteristics are animated in these ups and downs or zigs and zags. However, the appearance of new tags for narratology denotes lexical and terminological uncertainty and adds to a patent sense of semantic inadequacy for narratology as a discipline. Scholars in various areas muster up all possibilities to constitute some privileged explanatory narratologies. It seems that they would never wonder how many terms or categories can carry the full freight of the content of narratology as a discipline. Consequently, these cognate terms partially lose its original theoretical reference and further complicate its role as a discipline.

A telling case in point is that David Herman put these newly-termed narratologies under the term of "postclassical narratology" or "new narratologies" with one stroke. The oddness is that Herman asserts that postclassical narratology or new narratologies "dismiss classical narrative poetics as an outmoded framework for analysis, but to argue for its continued usefulness within certain limits" (Herman 1997, p. 1048), but "the prefix 'post' does not quite signify a clean break with structuralism,

Guoqiang Qiao

qiaoguoqiang@163.com

1 SISU, 550 West Dalian Road, Shanghai 200083, China 
whose many achievements are often worked into the new analyses (Routledge encyclopedia of narrative theory 450). That is, on the one hand, he asserts that his postclassical narratology "dismiss classical narrative poetics as an outmoded framework for analysis," yet on the other hand, he insists that "the prefix 'post' does not quite signify a clean break with structuralism." So why bother? Obviously, his split of narratology into classical and postclassical is problematic.

It might be arbitrary to say that Herman's split of narratology into classical and postclassical mixes up the travel of narratology in the West, but the predictable prospect is that his split does not help refine the basic theory of narratology and clarify the major features of some newly-appeared concepts and applications to make the concepts and applications more explanatory in the area of narrative studies. Contributors to this cluster of articles argue from different perspectives to demonstrate what has happened and how it has happened when narratology does not travel well in the West. The cluster begins with Guoqiang Qiao's article titled "Should narratology be split into classical and postclassical?", which questions the validity of Herman's of splitting narratology into classical and postclassical. He makes literature review of the split that Herman made in his articles and in Herman chief-edited Encyclopedia of narrative theory and exposes the paradox in Herman's split. By quoting Herman's iteration that the "postclassical" does not necessarily mean "poststructuralist," and "the prefix 'post' does not quite signify a clean break with structuralism" but an enriched theory that "draws on the concepts and methods to which classical narratologists did not have access" (Herman 1997, pp. 1048-1049), he contends Herman's confusion of the hierarchical with temporal relationship between the so-called classical narratology and postclassical narratology. For him, it would not make any sense to split such a discipline as narratology by making a temporal cut simply based on the different issues it focuses on.

Qiao also argues about the invalidity of Herman's as well as his followers' reproaches of the four mistakes (namely, "scientificity, anthropomorphism, disregard for context, and gender-blindness" Routledge encyclopedia of narrative theory, p. 450) that the so-called classical narratology has made. He takes Susan S. Lanser's proposal to establish feminist narratology for example and contend that the so-called classical narratology is not responsible for any of the four mistakes that Herman reproached. Narratology as a discipline is not gender-oriented but a general theory that intends to sort out the basic elements, models, and structures, and so on that constitute a narrative and figure out the basic rules that reveal the nature and law of a narrative construction. Based on the concept of non-exclusiveness that structuralism proposes, Qiao further argues that narratology also has this property of nonexclusiveness that helps take in and integrate some other related sciences or disciplines and thereof, serve as explanatory import to the construction of narratology.

Categorization is an efficient method for scientific research, which can help subtilize the whole business of the research. Yet Herman's effort to put all newlyappeared narrative concepts and practices under his postclassical category fails to refine narratology as a discipline from within. However, the articles in the cluster by Marie-Laure Ryan, Biwu Shang and Yue Gu set up effective examples that denote not only the theoretical relevance to the construction of narratology but also the categorical refinement of the narrative theory itself. 
To my knowledge, there are many scholars who have studied characters in fiction from various perspectives, but up to now there is no scholar who clearly announces to approach the issue of "character ontology" particularly from a narratological perspective. Marie-Laure Ryan tells us in her article titled "What are characters made of? Textual, philosophical and "world' approaches to character ontology" what the "character ontology" refers to for her. To clarify her "character ontology," Ryan proposes three related conceptions of fictional characters, which include (1) characters as collections of semes, (2) a truth value received from statements referring to characters, and (3) the characters from an internal point of view. The method she employs to argue about these three conceptions of fictional characters is to investigate them from the following three aspects: textualist, philosophical, and the world approach that she personally endorses. These three aspects together with the three conceptions constitute the main idea of her "character ontology," which helps reveal the essence of character in fiction. Specifically, based on structuralism, textualists claim that characters are not persons but objects made of language, or rather, "characters as collections of semes," whereas philosophers, especially those of the analytic schools, are concerned chiefly with the ontological status of fictional characters because for Ryan, this ontological status of fictional characters is "deeply entwined with the question of reference" and "some kind of existence." Ryan contends that a sentence about a non-existing entity is either necessarily false due to its referential failure or it is not false but indeterminate. The only criterion of validity for the claims of literary critics would be whether the non-existing entity is provocative enough to excite passions. However, for Ryan, these textualists' and philosophers' points of view are external.

Based on the theory of possible world Ryan proposes a third approach to the "character ontology" through the world as an internal point of view. She observes that the author of a fiction, who involves a doubling of world and a doubling of speech acts, pretends to be the narrator who resides in the storyworld. Meanwhile, the narrator presents the characters as real individuals. For Ryan, this "doubling" means that within the storyworld, characters have the same ontological status as the inhabitants of the real world. Yet, the question is how the reader regards the characters as actual individuals because they reside in a non-actual possible world created by the author. Ryan answers this question with the help of Lewis's indexical conception of actuality and possibility, as she believes the world approach can explain a phenomenon that neither the textual nor the philosophical approach is trying to deal with. In brief, Ryan brings us to be aware of the three conceptions and three aspects of character ontology, but she does not explain which of the conceptions or the aspects reflects the essence of the character ontology.

Péter Hajdu is concerned with another kind of narrator that is "collective narrator" in his article titled "The collective in the Hungarian narrative tradition and narrative studies." He discovers a road that is not taken yet so far particularly in the so-called postclassical years when narratologists focus their attentions on something "unnatural." Hajdu asserts that though Gérard Genette mentioned the possibility of a collective narrator as another kind of the narrator in a footnote of his Narrative discourse: An essay in method, the collective voice of a community takes an important role particularly in Hungarian narrative tradition. For Hajdu, 
the collective voice refers to a voice that usually cannot be attached to any particular speaker, but expresses a collective knowledge, the collective interpretation and evaluation of events and persons. Based on Alan Palmer's notion of social mind, which can be connected both to collective thought and collective narration, Hajdu argues that in Hungarian literary tradition, especially in the works of Kálmán Mikszáth (1847-1910), the collective voice of a community is frequently heard even in third-person narratives that otherwise seem to use a simple mimetic code. In addition, Hajdu also discusses communis opinio in Hungarian literary works, which is a term coined by Gyula Herczeg to describe the phenomenon that expresses a collective knowledge, the collective interpretation and evaluation of events and persons (or maybe the social mind). Hajdu contends with questions of narrator and its functions and its particular usages, which have a projection of current status of narrative studies. Disagreements and challenges may be made variedly regarding terminology, concepts, or nomenclatures, and so on, but they commonly denote the unwell traveling of Western narratology.

In recent years, the studies of emotion in narrative call for attention. Biwu Shang challenges the Western critics such as Hogan and David Herman that concern themselves only with the mimetic rather than the anti-mimetic aspects of emotion. He attacks that emotion has not been sufficiently explored in the Western narrative studies and not even being assigned a proper role in Phelan's conceptual system of rhetorical narratology. For him, contemporary avant-garde narratives foreground the fictionality of unnatural narratives and generate de-familiarizing effects. Based on this understanding and Alber and Heinze's notion of unnatural narrative, Shang takes contemporary avant-garde and anti-mimetic narratives for example to discuss the unnatural emotions and argues that stories are created by not only normal and usual emotions but also unnatural emotions. He also proposes four directions for future studies on unnatural emotion to embrace more unnatural aspects of narrative. One of the problems with Shang might be that whether or not the studies on unnatural emotions in unnatural narrative is necessarily constructed into "unnatural narratology," though several Western narratologists have already produced similar works on it, such as Jan Alber's Unnatural narrative: Impossible worlds in fiction and drama (2016) and collection of essays titled Unnatural narratives, unnatural narratology (2011) edited by Jan Alber and Rüdiger Heinze.

Along with Monika Fludernik's Toward a “natural” narratology (1996) and Brian Richardson's Unnatural voices (2006), the studies of unnatural narrative establish a particular terrain for the studies of narrative. For Fludernik, the term "unnatural narrative" refers to "the fabulous, the magical, and the supernatural besides the logically or cognitively impossible" (Fludernik, 362), whereas for Richardson, the term "unnatural narrative" is regarded as "one that conspicuously violates conventions of standard narrative forms, in particular the conventions of nonfictional narratives, oral or written, and fictional modes like realism that model themselves on nonfictional narratives" (Richardson, 34). Dávid Szolláth employs the basic ideas proposed by Fludernik and Richardson or some other narratologists such as J. Alber and S. Iverson to detect the phenomenon of unnaturalness in Hungarian postmodernist novels in his article "Inventory of magic, textual constructions of the unnatural in Hungarian postmodern fiction." He discusses different textual strategies 
and narrative traditions of "making magic" and, therefore, to consider the ability of resistance to naturalization and to draw some more general insights regarding the novels' modes of narration and generic structure. However, he contends that though the so-called unnatural narratives effectively deconstruct the realistic genres they invoked, they do not entirely break away from the illusion of reality and the illusory reliability of the narrator. In brief, he offers tenable arguments to demonstrate the unnaturalness in Hungarian postmodernist novels.

Indeed, emotion either in natural or unnatural narrative is an important issue to handle even though in formal studies. However, the basic function of narrative is not chiefly to preach the value of unnatural emotion that it does exist in human being's structure of feeling. In the same sense, narrative studies are not to overemphasize the significance of the stories and the emotions that are unnatural. Indeed, we are confronted with and sometimes frustrated by those unnatural things or emotions in life. Can narrative be any help for these confrontations or frustrations? Yue Gu gives us a positive answer to this question. He advances his understanding of narrative therapy in his article "Narrative, life writing, and healing: The therapeutic functions of storytelling," for which he has done three years of research and discovered that the process of healing through life writing can take place in a classroom setting characterized by openness and empathy. The method that he employs in his research proves that the twofold self (Self-1 and Self-2) can co-author life narratives and foster healing. Specifically, for $\mathrm{Gu}$, life narratives usually appear as a dialog between two selves: namely, Self-1 acts as the leading character as well as an involved narrator, whereas Self-2 acts as the narrator, listener, and counselor. Self-1 and Self-2 merge when an epiphany occurs in the author's writing that allows him or her to make sense of life experiences. Self- 2 has different perspectives and resources that Self-1 lacks and can re-narrate and assign new meanings to life experiences. Moreover, Self-2 deconstructs stereotypes and frees Self-1 from oppressive narratives by offering alternative life stories. Thus, a therapeutic relationship is established as the two selves share emotions through conversations and writing and re-writing of life narratives. Gu believes that healing, in essence, is the process of making sense of the life story and making peace with it.

Mikhail Bakhtin is one of the most outstanding Russian thinkers in the twentieth century. He is renowned for his unconventional book entitled Problems of Dostoevsky's poetics $(1929,1963,1984)$. His notions of three-part model of the human psyche together with the schema of "form-generating ideology" and his concept of "dialogized heteroglossia" gives rise to Bakhtin's theory of polyphony. However, for Jun Zeng, T. Todorov misunderstands Bakhtin, and believes that Bakhtin's theory is unfit for his own structuralist poetics. In his article "The tension within the specter of Bakhtin and narrative theory," Zeng asserts that Todorov is unsatisfied with Bakhtin's theory of polyphonic novel and deliberately confines Bakhtin's "dialogue" in the "quotations" of linguistics. From the standpoint of structuralism and formalism, Todorov concentrates more on structure, form, and rule. Zeng also discusses the direct or indirect influence of Bakhtin's literary theory on Wayne Booth and James Phelan, indicating that Bakhtin has experienced an uneven travel in the West.

Other Russian formalists' ideas also exert significant influence on narrative studies. One of the major hypotheses for the construction of narratology is the two basic 
opposed terms Fabula and Sjuzhet, which are employed by Russian formalists to respectively refer to "the basic story material" and "the set of narrated situations and events in order of their presentation to the receiver" (Prince 2003, 29, 89). However, she attempts to expose the impreciseness of the Western narrative terminology by making a nuanced examination of the terms Fabula and Sjuzhet particularly when they are employed in the analysis of Chinese lyric poetry and to uncover the potentials of narrative devices in analysis of lyric poetry. Specifically, in her "Exploring Fabula and Sjuzhet in Chinese classical poetry from the perspective of cognitive poetics," Linghong Shu proposes three particular characteristics of Fabula and Sjuzhet that are evidenced in Chinese lyric poems: first, fabula in lyric poetry consists of both material elements and lyrical elements; second, interpretation of Chinese eulogistic poems entails the comprehension of not only the events represented in the text but also the hyper-textual background of the poet; and third, understanding of space in lyric poems requires the knowledge of story, the discourse, the process of the poet's composition as well as reader's commitment. In a sense, Shu's findings unsettle the fossilized concepts of Fabula and Sjuzhet that the Western narratology has relied on it as a couple of the basic notions for the construction of narratology, representing one of the major theoretical pivots between the Western narrative concepts and the Chinese literary understanding.

At the turn of the new century some of narratologists developed a cognitive approach to narrative studies, signaling a cognitive turn that concerns itself chiefly in the relations between perception, language, knowledge, memory, and the world. In his essay "Framing surprise, suspense, and curiosity: A cognitive approach to emotional effects of narrative," Yuan Yuan presents a new theoretical perspective to address some major issues regarding cognitive studies of narrative, such as emotions in narrative experience, a perspective that proposes to examine readers' emotional engagements in context of the global sense-making process. To demonstrate its practical values, Yuan applies his framework to analyzing the three emotions of surprise, suspense, and curiosity in the process of reading. He challenges Meir Sternberg that the above-mentioned three emotions have a universal status for narrative and argues that frame-shifting, frame-completion, and frame-matching are the cognitive mechanisms respectively underlying these three emotions. In addition, he also calls the excessive concerns on emotion in question. For him, emotions can be analyzed regarding elementary cognitive processes and it is no longer plausible to take them as narrative's dominant interests.

Putting together, the authors of this cluster of articles express their concerns with the unstable traveling of narrative studies. They may vary in topics and arguments and arrive at different conclusions, but they all resist interpretive incertitude and theoretical confusion that run counter to the authentic claims of narrative studies. As a guest editor of this cluster of articles, I have no objection to any efforts to develop new theories and methods and enlarge new areas regarding narrative studies, but I insist that we must keep to the dominant important basis of narrative studies and the principal theoretical frameworks, particularly when we come to terms with the protean changes of cultural and historical specificity of narrative. The purposes of narrative studies may be vastly different, but the essence of narrative studies is to remain the same, that is, the exploration of narrative laws, principles, and the rules 
and the related issues that govern the dynamics of narrative, such as plot, character, theme, and the like.

\section{References}

Fludernik, M. (1996). Toward a "natural” narratology. London: Routledge.

Herman, D. (1997). Scripts, sequences, and stories: Elements of a postclassical narratology. PMLA, 112(5), 1046-1059.

Herman, D., Jahn, M., \& Ryan, M.-L. (Eds.). (2005). Routledge encyclopedia of narrative theory. London and New York: Routledge.

Hogan, P. C. (2011). Affective narratology: The emotional structure of stories. Lincoln: University of Nebraska Press.

Prince, G. (2003). A dictionary of narratology (Rev ed.). Lincoln and London: University of Nebraska Press.

Richardson, B. (2006). What is unnatural narrative theory? In J. Alber \& R. Heinze (Eds.), Unnatural narratives, unnatural narratology (pp. 23-40). Berlin: de Gruyter. 